\title{
RUMAH BACA PELANGI IBRAHIMY \\ DALAM UPAYA MENINGKATKAN MINAT BACA ANAK USIA SEKOLAH DI DESA KEDUNGREJO MUNCAR BANYUWANGI
}

\author{
Anis Hidayati MS \\ Institut Agama Islam (IAI) Ibrahimy Genteng Banyuwangi, Indonesia \\ e-mail: anis_mathematics@ymail.com
}

\begin{abstract}
"Rumah Baca Pelangi Ibrahimy" is a mini library initiated by Institut Agama Islam (IAI) Ibrahimy Genteng Banyuwangi students holding internship in 2020 at Kedungrejo Village, Muncar. The target of this program is the schoolage children in Kedungrejo Village, Muncar. It is a comfortable and educational public space for school-age children to make them easily obtain sources of reading, knowledge, and insights from provided books, in order to improve reading's interest especially the school-age children in this village. Methods used in this program are transparency, accountability, responsibility, independency, and fairness.
\end{abstract}

KEYWORDS : Reading House, Reading's Interest

\begin{tabular}{|c|c|c|}
\hline Accepted: & Reviewed: & Published: \\
January 07 2021 & January 14 2021 & February 15 2021 \\
\hline
\end{tabular}

\section{PENDAHULUAN}

Kemunculan wabah virus Corona (Covid-19) menjadi salah satu sebab tidak stabilnya sirkulasi kehidupan bangsa ini. Mulai dari sektor ekonomi seperti kacaunya regulasi pekerja yang mengharuskan adanya pembaharuan regulasi sehingga berimbas pada dirumahkannya sebagian pekerja alias PHK selama pandemi. Ada banyak perusahaan besar maupun kecil yang gulung tikar akibat pandemi ini. Selain sektor ekonomi, yang menjadi perhatian khusus adalah pada sektor pendidikan, sehingga beberapa negara memutuskan untuk menutup sekolah maupun perguruan tinggi. Di Indonesia pemerintah menginstruksikan untuk menyelenggarakan Pembelajaran Jarak Jauh (PJJ) / Daring sebagai upaya mencegah penyebaran virus Covid-19 melalui Surat Edaran Kementerian Pendidikan dan Kebudayaan (Kemendikbud) Direktorat Pendidikan Tinggi No.1 Tahun 2020 (Handarini \& Wulandari, 2020: 496). Sebagaimana (Rushdiyah, 2019) dalam (Hakim \& Zainiyati, 2021), Pembelajaran dalam jaringan (daring) 
yang populer dengan istilah online learning seringkali dianggap sama dengan pembelajaran elektronik (e-learning), padahal ada perbedaan yang signifikan pada keduanya namun masih saling berkaitan antara satu dengan yang lain. Karena pada dasarnya pembelajaran dalam jaringan juga merupakan bagian dari pembelajaran elektronik

Pada penerapan pembelajaran Daring membutuhkan dukungan perangkatperangkat mobile seperti laptop, komputer, smartphone, dll agar dapat mengakses informasi kapan saja dan dimana saja. Perangkat-perangkat tersebut tidak dapat bekerja secara optimal tanpa adanya internet dengan aksesibilitas, fleksibilitas dan konektivitas yang tinggi, sehingga menjadi kesulitan tersendiri bagi guru, orang tua maupun siswa. Kesulitan yang dirasakan oleh siswa dalam pembelajaran Daring membuat para siswa kurang berminat terhadap pembelajaran Daring yang dilaksanakan saat ini. Kurangnya minat siswa terhadap pembelajaran Daring di Indonesia dapat ditunjukkan oleh diagram berikut :

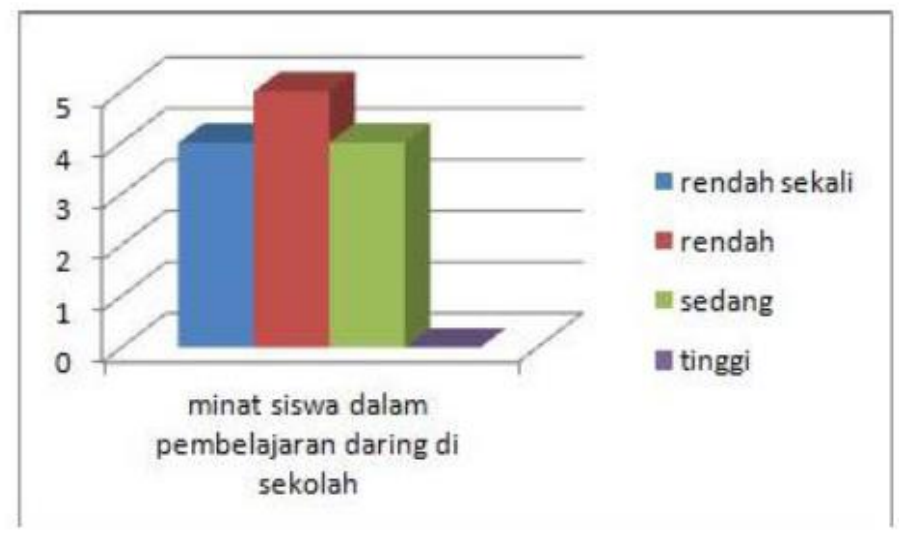

Sumber : Kompasiana.com, 2020

Kurangnya minat siswa dalam mengikuti pembelajaran Daring menjadikan aktivitas siswa dalam membaca juga berkurang, berkurangnya aktivitas membaca berdampak pada kurangnya minat baca anak pada usia sekolah. Padahal kemampuan membaca disertai dengan kebiasaan membaca yang kuat akan menciptakan SDM yang berkualitas, sehingga target pemerintah untuk meningkatkan perekonomian rakyat dapat tercapai (Muktiono, 2003:10).

Kemampuan membaca dan kebiasaan membaca yang kuat harus dilatih sejak dini yaitu pada usia sekolah TK hingga sekolah menengah. Tentu saja untuk menumbuhkan minat baca pada usia sekolah tidaklah mudah, apalagi 
65 | Rumah Baca Pelangi Ibrahimy Dalam Upaya Meningkatkan Minat Baca Anak Usia Sekolah Di Desa Kedungrejo Muncar Banyuwangi

dengan adanya pandemi seperti sekarang ini. Oleh karena itu, kehadiran perpustakaan di tengah-tengah masyarakat, khususnya anak usia sekolah sangatlah penting. Perpustakaan sebagai lembaga yang bertugas untuk meningkatkan minat baca, harus memiliki rencana atau strategi sebagai tahapan awal untuk menarik minat pengunjung perpustakaan (Rahma, dkk, 2015:764).

Berdasarkan uraian di atas maka peran KKN Tematik Era Covid-19 di Desa Kedungrejo Muncar tahun 2020 berfokus pada pembangunan perpustakaan mini ditengah-tengah masyarakat, khususnya anak-anak, sebagai bentuk upaya dalam meningkatkan minat baca anak usia sekolah. Dalam pembangunan rumah baca ini tidak luput dari peran dari berbagai pihak, baik dari mahasiswa, para dosen juga masyarakat. Oleh karena itu, untuk meminimalkan berbagai macam konflik dari berbagai pihak yang terkait, serta meningkatkan kinerja berbagai pihak dalam proses pembangunan, perlu kiranya perencanaan yang matang dan sistematis, dengan penggunaan metode transparency, accountability, responsibility, independency, dan fairness (Bakti \& Praptiningsih, 2014:1).

Perpustakaan mini yang dirintis oleh mahasiswa KKN Tematik Era Covid-19 IAI Ibrahimy Genteng tahun 2020 ini diberi nama "Rumah Baca Pelangi Ibrahimy", yang bertujuan untuk meningkatkan minat baca pada anak usia sekolah di Desa Kedungrejo Muncar Banyuwangi.

\section{METODE PELAKSANAAN}

Rumah Baca Pelangi Ibrahimy sebagai wujud pengabdian kepada masyarakat didirikan dengan memanfaatkan lahan kosong di halaman Musholla An-Nur yang terletak di perumahan AA Regency, sebagai salah satu alternatif penyediaan ruang publik yang nyaman, dan edukatif. Selain berfungsi sebagai tempat baca, Rumah Baca Pelangi Ibrahimy juga berfungsi sebagai sarana bermain dan mengekspresikan diri bagi anak - anak untuk sekedar melepas penat di tengah-tengah belajar online (Daring).

Proses pembangunan Rumah Baca Pelangi Ibrahimy menggunakan beberapa metode agar pelaksanaan pembangunan berjalan dengan lancar, metode yang digunakan sebagai berikut :

a. Metode Transparancy (Keterbukaan)

Maksudnya adalah masyarakat harus mengetahui kejelasan maksud, tujuan, sasaran dan alokasi dana kegiatan pembangunan Rumah Baca Pelangi Ibrahimy, agar masyarakat dapat mendukung, membantu dan mengawasi pelaksanaan kegiatan, serta dapat mencegah ketertutupan dan 
kesimpangsiuran informasi yang dapat menghambat pelaksanaan kegiatan ini.

b. Metode Accountability (dapat dipertanggungjawabkan)

Penerapan Accountability pada pembangunan dan pelaksanan Rumah Baca Pelangi Ibrahimy merupakan pembagian struktur organisasi yang jelas, dan apa saja fungsi dari masing - masing posisi tersebut. Struktur organisasi, fungsi dari masing - masing posisi, serta bagaimana pelaksanaannya nanti, semua tertulis dalam SOP, hal ini bertujuan untuk meminimalisir terjadinya tumpang tindih tanggug jawab.

c. Metode Responsibility (Tanggung Jawab)

Responsibility memiliki makna tanggung jawab, maksudnya setiap individu harus: (1) Sadar, yaitu setiap individu harus mengetahui/mengenal tugasnya masing - masing; (2) cinta atau suka pada tugasnya, karena jika seseorang itu suka atau cinta maka akan menimbulkan rasa kepatuhan, kerelaan, dan kesediaan berkorban; (3) Berani, yaitu setiap individu tidak ragu - ragu dan tidak takut dengan segala rintangan dalam menjalankan fungsinya. Jadi pada prinsipnya tanggung jawab dalam arti Responsibility lebih menekankan pada suatu perbuatan yang harus dilakukan secara sadar dan siap untuk menerima konsekuensinya.

d. Metode Independency (Bebas)

Maksud dari Indenpendncy adalah masing - masing individu atau posisi tidak saling mendominasi dan tidak dapat diintervensi oleh pihak lain.

e. Metode Fairness (Keadilan)

Penerapan metode Fairness yaitu memberikan hak dan kesempatan yang sama pada semua pihak.

\section{HASIL DAN PEMBAHASAN}

Bagian ini menjelaskan tentang hasil dan pembahasan dalam proses pendirian Rumah Baca Pelangi Ibrahimy dari awal hingga peresmian. Dimana proses pembangunannya melewati beberapa tahapan sebagai berikut :

1. Tahap Perencanaan (Planning)

Pada saat mahasiswa KKN di Desa Kedungrejo Muncar terbentuk, mahasiswa mengadakan pertemuan terlebih dahulu di rumah Dosen Pembimbing Lapangan (DPL) untuk mengenal satu sama lain, karena semua anggota KKN beserta DPL berasal dari Kecamatan Muncar maka sedikit banyak mahasiswa dan DPL sudah mempunyai gambaran tentang kondisi 
67 | Rumah Baca Pelangi Ibrahimy Dalam Upaya Meningkatkan Minat Baca Anak Usia Sekolah Di Desa Kedungrejo Muncar Banyuwangi

yang ada di sekitar Kecamatan Muncar, dari hasil diskusi terdapat beberapa gambaran masalah yang ada seperti masalah ekonomi, sosial, budaya, dan pendidikan. Untuk memastikan tentang hal itu, maka mahasiswa berencana untuk mengadakan observasi terlebih dahulu sebagai langkah dalam mengidentifikasi masalah yang ada.

a. Identifikasi Masalah

Proses identifikasi masalah dilakukan melalui aktivitas observasi seperti yang sudah direncanakan, observasi dilakukan setelah penerjunan mahasiswa KKN selesai, penerjunan dilaksanakan pada hari Rabu tanggal 10 Juni 2020. Menurut keterangan dari Kepala Desa Kedungrejo yaitu BPK. Ahmad Zaiho bahwa Desa Kedugrejo terdiri dari 6 Dusun yaitu: Dusun Duaraan, Kalimati, Krajan, Muncar, Sampangan, dan Stoplas. Observasi dilakukan selama 3 hari di 6 dusun tersebut. Dari hasil observasi ditemukan beberapa masalah, salah satunya tentang pendidikan, yaitu kurangnya minat baca pada anak usia sekolah. Oleh karena itu mahasiswa Berencana mendirikan perpustakaan mini yang ramah anak agar mereka tertarik untuk mengunjungi perpustakaan ini.

Rencana ini mahasiswa sampaikan terlebih dahulu kepada Kepala Desa Kedungrejo, dengan tujuan mendapatkan izin, dukungan dan masukan dari beliau yang berkenaan dengan rencana pembangunan perpustakaan mini ini. Respon dari Kepala Desa sangat baik, beliau mengizinkan dan mendukung kegiatan ini, bahkan ada beberapa masukan dari beliau seperti lokasi yang tepat, serta gambaran tentang karakter masyarakat dan anak - anak yang ada di Desa Kedungrejo sehingga dapat dijadikan pertimbangan dalam desain perpustakan mini yang akan di beri nama "Rumah Baca Pelangi Ibrahimy" tersebut.

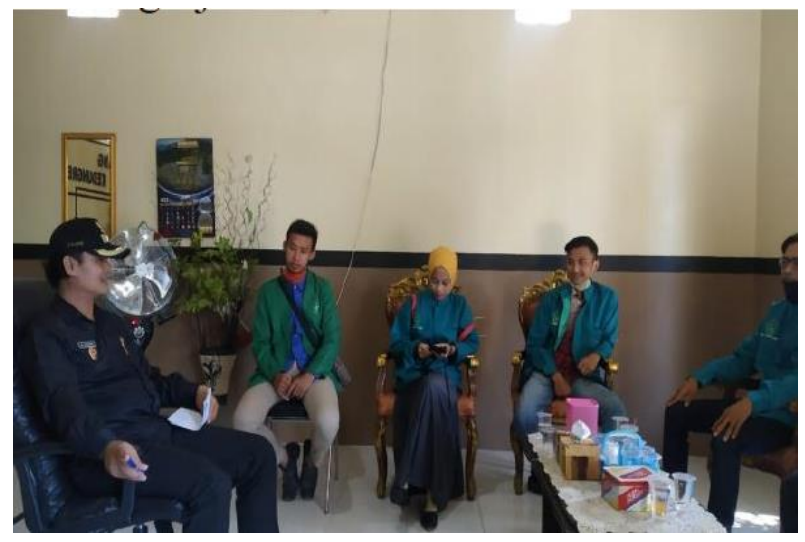

Gambar 1 Diskusi peta konsep kegiatan KKN bersama Kepala Desa Kedungrejo 
Setelah mendapatkan izin dan beberapa masukan dari Kepala Desa, beliau juga mengantarkan mahasiswa menemui warga sekitar lokasi perpustakaan mini yang mahasiswa rencanakan akan didirikan. Disana mahasiswa menyampaikan kejelasan maksud, tujuan, sasaran hingga alokasi dana kegiatan dalam mendirikan Rumah Baca Pelangi Ibrahimy (Transparancy) dengan tujuan agar masyarakat turut mendukung, membantu dan mengawasi pelaksanaan kegiatan, serta dapat mencegah ketertutupan dan kesimpangsiuran informasi yang dapat menghambat pelaksanaan kegiatan ini. Setelah mahasiswa menjelaskan semuanya, program ini mendapatkan sambutan yang luar biasa, warga sangat senang dan antusias dengan program-program yang sudah direncanakan oleh mahasiswa salah satunya tentang perpustakaan mini tersebut.

b. Penyusunan Program Kegiatan Pembangunan

Tahap dimana penyusunan kerangka konsep dan langkah - langkah dalam kegiatan pembangunan program Rumah Baca Pelangi Ibrahimy yang rencananya akan dibangun di perumahan AA Regency Kedungrejo Muncar sekaligus perencanaan terjalinnya kerja sama dengan pihak eksternal dimana hal ini Komunitas Rumah Baca Ikan Muncar menjadi kolabor sekaligus penaung untuk menindak lanjuti program rumah baca pasca KKN 2020 selesai.

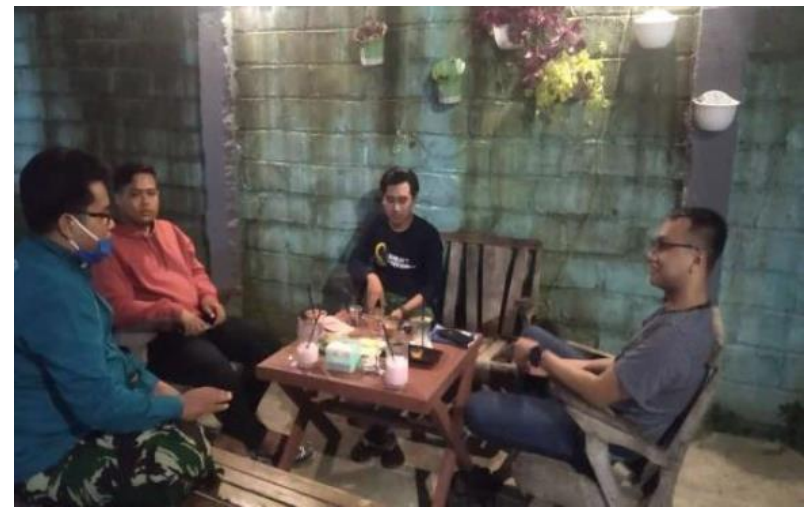

\section{Gambar 2 Pertemuan dengan Komunitas Rumah Baca Ikan Muncar}

Selain menyusun kerangka dan langkah - langkah dalam melaksanakan pembangunan program Rumah Baca Pelangi Ibrahimy mahasiswa beserta Komunitas Rumah Baca Ikan Muncar juga menyusun SOP. SOP disusun untuk memperjelas perincian atau standar yang tetap mengenai aktivitas di Rumah Baca Pelangi Ibrahimy sehingga meminimalisir terjadinya tumpang tindih tanggug jawab (Accountability), dengan harapan SOP tersebut dapat 
69 | Rumah Baca Pelangi Ibrahimy Dalam Upaya Meningkatkan Minat Baca Anak Usia Sekolah Di Desa Kedungrejo Muncar Banyuwangi

menjadikan arus kerja yang lebih baik, menjadi panduan untuk petugas pelaksananya (Responsibility), penghematan biaya, memudahkan pengawasan, serta menjadi koordinasi yang baik antara bagian-bagian yang berlainan dalam organisasi rumah baca tersebut.

c. Sosialisasi Program Kegiatan Pembangunan

Pada tahap ini semua yang sudah disusun oleh mahasiswa dan Komunitas Rumah Baca Ikan Muncar di sosialisasikan kepada perwakilan warga perumahan AA regency tempat dimana rumah baca akan dibangun. Kegiatan Sosialisasi ini menghasilkan beberapa kesepakatan yang mengacu pada adanya relevansi program yang mahasiswa susun dengan keinginan warga sekitar, diantara hasil yang diperoleh adalah adanya keinginan terciptanya ruang publik yang nyaman untuk anak-anak dalam belajar dan bermain. Adanya sebuah inovasi fungsi rumah baca yang tadinya hanya sebagai tempat literasi untuk anak-anak, difungsikan juga sebagai wahana untuk berekspresi dibidang seni maupun kegiatan lain yang mengandung unsur pendidikan. Oleh karena itu, Rumah Baca Pelangi Ibrahimy nantinya harus didesain semenarik mungkin untuk anak-anak, seperti halnya tembok yang diberi gambar karakter atau lukisan alam, dan tersedianya ruangan bermain/berekspresi untuk anak-anak.

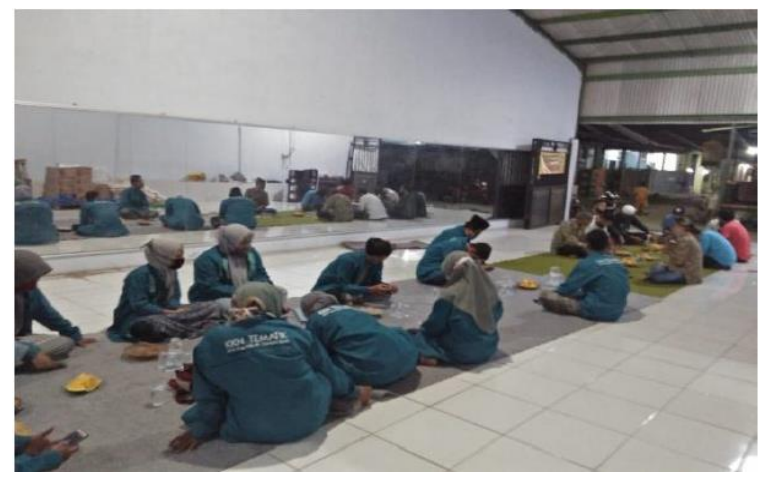

\section{Gambar 3 Sosialisasi program Rumah Baca Pelangi Ibrahimy}

\section{Tahap Pelaksanaan}

Pada tahap ini mahasiswa bersama warga perumahan AA Regency Kedungrejo Muncar melaksanakan pembangunan. Pelaksaan pembangunan di mulai pada hari Senin tanggal 15 Juni 2020 dan selesai pada hari Rabu tanggal 22 Juli 2020, kemudian Rumah Baca Pelangi Ibrahimy diresmikan pada hari Kamis tanggal 23 Juli 2020, bersamaan dengan berakhirnya masa KKN. Berikut rincian pelaksanaannya : 
a. Pembangunan Tahap I

Pembangunan tahap I dimulai dari mempersiapkan bahan baku bangunan seperti pasir dan besi, dimana bahan bangunan tersebut didapat dari sumbangan warga sekitar. Kemudian memindahkan bahan bangunan tersebut dari tempat semula yaitu pinggir jalan ke lokasi rumah baca akan dibangun yaitu halaman musholla An-Nur. Kegiatan ini dilaksanakan pada hari Senin tanggal 15 Juni 2020 dibantu oleh warga sekitar. Kegiatan dimulai pada pukul 08.00 WIB sampai pukul 17.00 WIB.

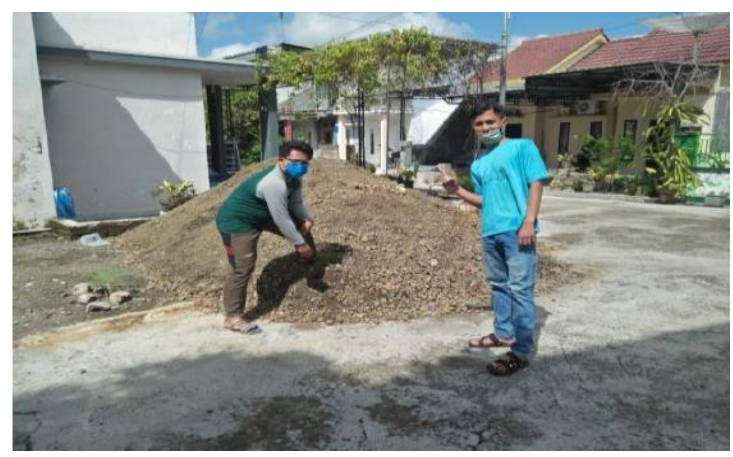

Gambar 4 Pembangunan Tahap I

b. Pembangunan Tahap II

Pada tahap ini pembangunan Rumah Baca Pelangi Ibrahimy dimulai, mulai dari awal pengecoran bidak lantai sampai pada pondasi bangunan. Kegiatan ini dilaksanakan pada hari Minggu tanggal 21 Juni 2020, dimulai pada pukul 06.00 WIB sampai pukul 12.00 WIB.

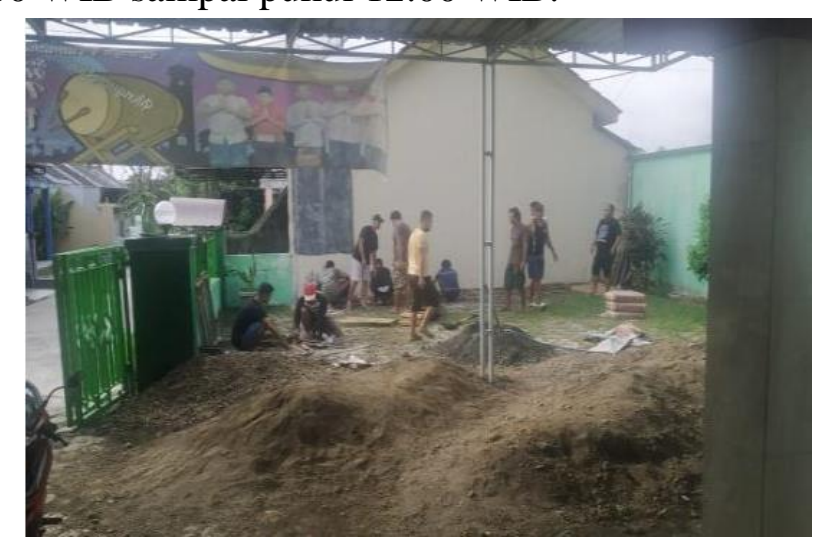

Gambar 5 Pembangunan Tahap II (Pengecoran)

Kegiatan dilakukan mahasiswa bersama dengan warga sekitar dengan ditandainya proses peletakan batu pertama yang bersamaan dengan kegiatan 
71 | Rumah Baca Pelangi Ibrahimy Dalam Upaya Meningkatkan Minat Baca Anak Usia Sekolah Di Desa Kedungrejo Muncar Banyuwangi

Khotmil Qur'an di musholla An-Nur. Kegiatan ini menghasilkan bidak lantai dan pondasi calon Rumah Baca Pelangi Ibrahimy

c. Pembangunan Tahap III

Tahap ini merupakan tahap akhir pembangunan (Finishing). Proses ini diawali dari penataan landscape lokasi rumah baca, dan menggambar serta mengecat tembok rumah baca dengan lukisan yang edukatif dan inspiratif, dengan harapan bisa menjadi daya tarik bagi anak-anak untuk berkunjung ke Rumah Baca Pelangi Ibrahimy. Kegiatan ini dilaksanakan pada hari Rabu tanggal 22 Juli 2020, dimulai pukul 06.00 WIB sampai pukul 23.30 WIB.

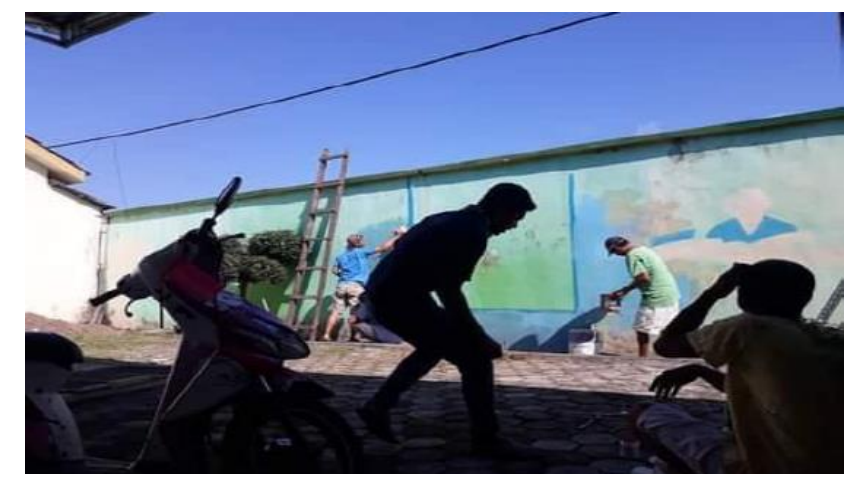

Gambar 6 Pembangunan Tahap III (Finishing)

d. Pengadaan Fasilitas Pendukung

Dalam menyukseskan berdirinya Rumah Baca Pelangi Ibrahimy ini, tentunya harus ada fasilitas pendukung untuk menunjang fungsi dari rumah baca itu sendiri, seperti rak buku, beserta isinya. Untuk rak buku mahasiswa membuat sendiri dengan memanfaatkan bahan baku (bambu) yang ada disekitar rumah mahasiswa, pembuatan rak buku dilakukan pada hari Rabu tanggal 01 juli 2020.

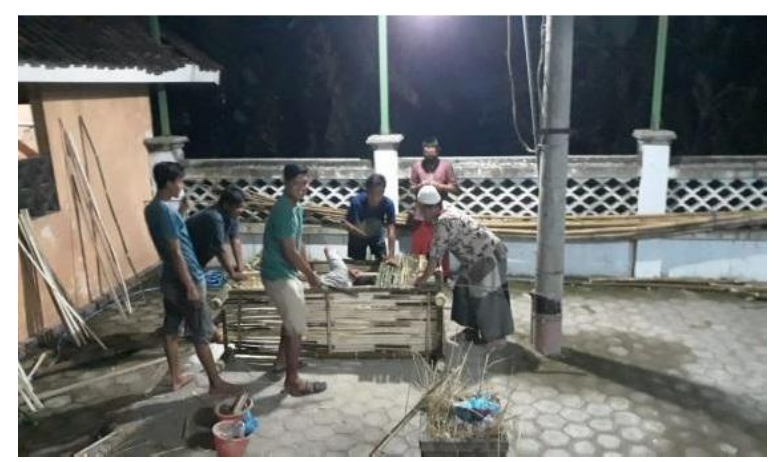

Gambar 7 Proses pembuatan rak buku 
Sedangkan untuk isinya (buku), mahasiswa mengumpulkannya lewat program sedekah buku, dimana tim penjemput buku mendatangi para donatur yang ingin berkontribusi dalam program sedekah buku ini.

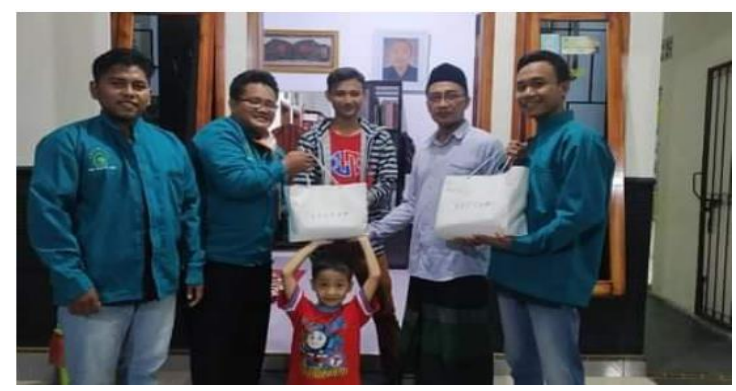

\section{Gambar 8 Pengambilan buku dari rumah donatur}

Pada dasarnya penggalangan buku ini bukan hanya sekedar ajakan untuk mensedekahkan buku saja, namun juga sebagai gerakan literasi yang sedang gencar-gencarnya dilakukan pemerintah untuk memutus mata rantai kebodohan bangsa ini, hal ini dimulai dari kepedulian kita untuk memberikan fasilitas kepada para generasi selanjutnya. Rumah Baca Pelangi Ibrahimy dibangun tidak berdasarkan kepentingan suatu kelompok tertentu (Independency), tapi rumah baca ini dibangun berdasarkan kesadaran warga terhadap pentingnya membaca bagi generasi bangsa. Dari awal pembangunan hingga selesai, semua warga mempunyai hak dan kesempatan yang sama untuk ikut serta dalam pembangunan rumah baca ini (Fairness).

\section{e. Peresmian}

Setelah pembangunan selesai dari tahap awal hingga akhir, tibalah saatnya Rumah Baca Pelangi Ibrahimy diresmikan. Peresmian dilaksanakan pada hari Kamis tanggal 23 Juli 2020 yang bertempat di halaman musholla An-Nur sekaligus bersamaan dengan acara pelepasan mahasiswa KKN, karena masa KKN Tematik Era Covid-19 IAI Ibrahimy Genteng tahun 2020 sudah berakhir. 
73 | Rumah Baca Pelangi Ibrahimy Dalam Upaya Meningkatkan Minat Baca Anak Usia Sekolah Di Desa Kedungrejo Muncar Banyuwangi

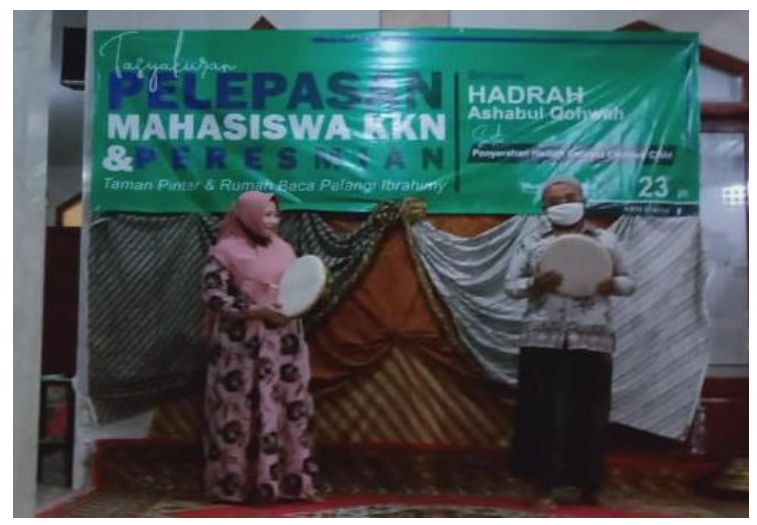

\section{Gambar 9 Peresmian Rumah Baca Pelangi Ibrahimy}

3. Tahap Evaluasi

Tahap Evaluasi diadakan bersama warga perumahan AA Regency, dalam evaluasi ini ada poin penting yang harus diperhatikan yaitu keberlanjutan dari rumah baca inii selepas kegiatan KKN selesai, agar Rumah Baca Pelangi Ibrahimy bisa berfungsi dengan baik sebagai sarana dalam upaya meningkatkan minat baca anak usia sekolah meskipun para mahasiswa KKN sudah tidak lagi disana.

\section{SIMPULAN}

Program Rumah Baca Pelangi Ibrahimy merupakan salah satu program mahasiswa KKN Tematik Era Covid-19 IAI Ibrahimy tahun 2020 yang dilaksanakan di Desa Kedungrejo Muncar Banyuwangi. Lokasi Rumah Baca Pelangi Ibrahimy berada di halaman musholla An-Nur AA Regency, sebagai ruang publik yang nyaman dan edukatif bagi anak -anak, yang bertujuan untuk meningkatkan minat belajar anak usia sekolah. Rumah baca ini dibangun dengan menggunakan metode transparency, accountability, responsibility, independency, dan fairness. Proses pembangunan Rumah Baca Pelangi Ibrahimy melalui beberapa tahapan seperti, (1) Tahap Perencanaan (Planning), (2) Tahap Pelaksanaan, (3) Tahap Evaluasi.

\section{DAFTAR RUJUKAN}

Bakti, Sharron N.R, dan Praptiningsih, Maria. 2014. Penerapan Transparancy, Accountability, Responsibility, Independency, dan Fairnesss pada Perusahaan Keluarga PT. Anugerah Putra Siantan Di Malang - Jawa Timur. Jurnal Agora vol.2, No.1 
Handarini, Oktafia I, dan Wulandari, Siti S. 2020. Pembelajaran Daring Sebagai Upaya Study From Home (SFH) Selama Pandemi Covid 19. Unesa:Jurnal pendidikan Administrasi Perkantoran (JPAP) Vol.8, No.3

Hakim, L., \& Zainiyati, H. S. (2021). Penggunaan Online Learning Pada Matakuliah Hermeneutika Al Quran (Studi Terhadap Mahasiswa Semester Vi Stai Al Anwar Sarang Rembang). Tarbiyatuna: Kajian Pendidikan Islam, 5(1), 1-14.

Muktiono, Joko D. (2003). Aku cinta buku: Menumbuhkan minat baca pada anak. Jakarta, Elex Media Komputindo

Rahma, Nurida M, dkk. 2015. Strategi Peningkatan Minat Baca Anak (Studi pada Ruang Baca Anak Perpustakaa Umum dan Arsip Daerah Kota Malang). Jurnal Administrasi Publik (JAP) Vol.3, No.5 